\title{
Interactive comment on "Variations in mineralogy of dust in an ice core obtained from northwestern Greenland over the past 100 years" by Naoko Nagatsuka et al.
}

\section{Anders Svensson (Referee)}

as@gfy.ku.dk

Received and published: 26 December 2020

The manuscript is concerned with a century long dust record obtained from the northwestern Greenland SIGMA-D ice core. The dust is characterized in terms of mineralogy (SEM+EDS), size and roundness at 5-year resolution. Furthermore, a trajectory analysis is performed in order to track the origin of the dust. It is found that the dust is a mixture of local dust and dust from more distant sources and that the fraction of local dust varies with coastal weather and snow cover. 
The manuscript is generally making a good case describing the dust variability in Northwestern Greenland of the last century. To investigate the dust source, it would however be very helpful to have a few isotopic analyses of $\mathrm{Sr}$ or $\mathrm{Nd}$ that are probably more indicative of the dust origin than the mineralogy and certainly more informative than eg the roundness parameter. The argumentation and thus the conclusions concerning the dust source being at high, mid or low latitudes based on mineralogy are in my view somewhat weak without the isotopes. Likewise, the lack of isotopic analyses makes comparison to similar analyses from many other Greenland ice cores impossible. Indeed, it would be a surprise if we have substantial amounts of low latitude dust deposited in Northern Greenland today.

I have my doubts about the trajectory analysis suggesting that none of the dust in the ice core originates from Asia. Large Asian dust clouds are observed on satellite images following the dominating westerly wind pattern. During the last glacial the majority of the Greenland dust had this source. Likewise, several tephra studies show that volcanic material of high-latitude Asian and Alaskan origin makes it to Greenland, whereas no tephra from Europe or lower latitudes ever made it to Greenland to my knowledge. Today the major Greenland dust source is less well-known and a more local dust contribution certainly is a possibility, but I would suspect a fraction of the dust still to originate in Asia today. Without the isotopic tracers, however, it is difficult to know, and trajectory analysis may not tell the complete story. Please compare your trajectory analysis to that made in Schüpbach et al., 2018, and comment on differences in methodology and results. In particular, Schüpbach et al., 2018, supplementary figure 1 may be relevant.

In Simonsen et al., 2019 (full reference below), the dust size distribution (or the contribution of large fraction particles) is seen as a strong indicator of local versus distant dust sources. Large particles cannot be transported over long distances, so the presence of large particles in the ice core is attributed to local dust sources. Does the dust size distributions in your study support your conclusions of local versus long-range dust

CPD

Interactive comment
Printer-friendly version

Discussion paper

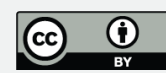




\section{source variations?}

I find the manuscript is generally well written with good figures and referencing, except the introduction that I think needs a rework both language-wise and concerning references. The cited papers appear not to be up to date; below I give some additional suggestions for recent work that I think should be referred to and possibly commented on.

Specific comments:

Mention the name of the analysed ice core in the title or in the abstract.

It would be relevant to cite this recent paper in the introduction, since the idea of more local dust in Greenland ice cores is also discussed here although on a different time scale:

Simonsen, M. F., Baccolo, G., Blunier, T., Borunda, A., Delmonte, B., Frei, R., Goldstein, S., Grinsted, A., Kjær, H. A., Sowers, T., Svensson, A., Vinther, B., Vladimirova, D., Winckler, G., Winstrup, M., and Vallelonga, P.: East Greenland ice core dust record reveals timing of Greenland ice sheet advance and retreat, Nature Communications, 10, 10.1038/s41467-019-12546-2, 2019.

I. 19.: 'changed periodically' leaves the impression that the dust composition varies with a certain periodicity, ie with a certain frequency. Probably the authors mean to say that the dust had different composition in different periods?

I. 23.: 'This indicates...' -> 'Comparison to Greenland surface temperature records indicates. ..'

I. 24.: 'The trajectory ...' -> 'A trajectory...' or 'Trajectory...'

I. 30.: 'Past dust composition...' -> 'Past ice-core dust composition records have revealed substantial variations in the concentration...' It is unclear which time period you refer to here. Is this about glacial cycles (Antarctica), the last glacial cycle, the
CPD

Interactive

comment
Printer-friendly version

Discussion paper

3 
Holocene, historical times, or on a seasonal time scale? With this postulate you need to cite a reference.

I. 31-32.: 'climate signals'. Are you referring to ice core water isotopes? 'atmospheric circulation', what is referred to here? Again the time period is not specified. Again you will need to cite published work for this statement.

I. 29-40.: I think you also need to cite at least some of those classic studies:

Interactive

Ruth, U., Wagenbach, D., Steffensen, J. P., and Bigler, M.: Continuous record of microparticle concentration and size distribution in the central Greenland NGRIP ice core during the last glacial period, Journal of Geophysical Research, 108, 10.1029/2002jd002376, 2003.

Petit, J. R., Mounier, L., Jouzel, J., Korotkevich, Y. S., Kotlyakov, V. I., and Lorius, C.: Palaeoclimatological and chronological implications of the Vostok core dust record, Nature, 343, 56-58, 1990.

Lambert, F., Delmonte, B., Petit, J. R., Bigler, M., Kaufmann, P. R., Hutterli, M. A., Stocker, T. F., Ruth, U., Steffensen, J. P., and Maggi, V.: Dust-climate couplings over the past 800,000 years from the EPICA Dome C ice core, Nature, 452, 616-619, 2008.

I. 42.: What is meant by 'rarely'? Do you have evidence of changing isotopic rations during transport? If so, please cite relevant reference.

I. 41-50.: You probably should cite some of the more recent papers as well:

Újvári, G., Stevens, T., Svensson, A., Klötzli, U. S., Manning, C., Németh, T., Kovács, J., Sweeney, M. R., Gocke, M., Wiesenberg, G. L. B., Markovic, S. B., and Zech, M.: Two possible source regions for central Greenland last glacial dust, Geophysical Research Letters, 42, 10399-10408, 10.1002/2015GL066153, 2015.

Han, C., S. D. Hur, Y. Han, K. Lee, S. Hong, T. Erhardt, H. Fischer, A. M. Svensson, J. P. Steffensen, P. Vallelonga. High-resolution isotopic evidence for a po-

Printer-friendly version

Discussion paper 
tential Saharan provenance of Greenland glacial dust. Scientific Reports 8:15582 | DOI:10.1038/s41598-018-33859-0 3, 2018. I. 51-60.:

CPD

Probably you should cite this paper:

Obbard, R. W., Baker, I., and Prior, D. J. (2011). Instruments and Methods A scanning electron microscope technique for identifying the mineralogy of dust in ice cores. Journal of Glaciology 57, 511-514.

I. $63 .:$ ' . . in the ice sheet' $->$ '. . . to the ice sheet'.

I. 61-72.: This recent paper would also be relevant for the introduction:

Zhang, P., Jeong, J.-H., Yoon, J.-H., Kim, H., Wang, S.-Y. S., Linderholm, H. W., Fang, K., Wu, X., and Chen, D.: Abrupt shift to hotter and drier climate over inner East Asia beyond the tipping point, Science, 370, 1095-1099, 10.1126/science.abb3368.

I. 179.: 'Dating of the SIGMA-D ice core, which was performed by annual layer counting of $\delta 180$ and $\mathrm{Na}+$, showing obvious seasonal variations (Fig. A1).' -> 'Dating of the SIGMA-D ice core was performed by annual layer counting of $\delta 180$ and $\mathrm{Na}$ + that show obvious seasonal variations (Fig. A1).'

I. 246.: 'cyclically' suggests a periodicity or frequency. What is the period or frequency on two different time scales referred to?

I. 250.: Are you suggesting a major contribution of low to mid-latitude dust to Northern Greenland for the period 1950-2004? What is the potential source area and why should it be turned on in 1950 and off in 2004?

I. 309.: 'Previous studies...' What are those previous studies and are they concerned with dust transport to Greenland in the last century?

Interactive comment on Clim. Past Discuss., https://doi.org/10.5194/cp-2020-146, 2020.
Interactive comment
Printer-friendly version

Discussion paper 